\title{
Enhancing the Teaching-Learning Process through Collaborative Learning
}

\author{
Sathyendra Bhat ${ }^{1}$, Ragesh Raju ${ }^{2}$, Shreeranga Bhat ${ }^{3}$, Rio D'Souza ${ }^{4}$ \\ ${ }^{1}$ Department of Computer Applications, St Joseph Engineering College, Mangaluru, Karnataka, India \\ ${ }^{2}$ Department of Computer Applications, St Joseph Engineering College, Mangaluru, Karnataka, India \\ ${ }^{3}$ Department of Mechanical Engineering, St Joseph Engineering College, Mangaluru, Karnataka, India \\ ${ }^{4}$ Department of Computer Science and Engineering, St Joseph Engineering College, Mangaluru, Karnataka, India \\ ${ }^{1}$ sathyendrab@sjec.ac.in \\ ${ }^{2}$ rageshr@sjec.ac.in \\ ${ }^{3}$ shreerangab@sjec.ac.in \\ ${ }^{4}$ riod@sjec.ac.in
}

\begin{abstract}
In the modern era, the education system has undergone a huge paradigm shift. Traditional classroom teaching methodologies that used to work like wonder, no longer attract the students of the present generation. Higher education, especially, engineering education has been greatly impacted by this paradigm shift and things are rapidly moving away from traditional methods to more advanced and innovative active learning strategies. Collaborative Learning is one of the popular forms of active learning and caters to the needs of millennial learners of today. This study deals with the impact of Team-GamesTournament (TGT), which is one of the Collaborative Learning techniques. The outcomes of this small experiment clearly show that when Collaborative Learning is leveraged well, it surely results in better learning among the students.
\end{abstract}

Keywords: Higher Education, Engineering Education, Teaching-Learning, Active Learning, Collaborative Learning

\section{Introduction}

The traditional approach to teaching was most often than not, teacher-centric. The teacher was believed to be the source of knowledge, which eventually was transferred to students through classroom teaching. In the modern-day and age, where internet rules the roost, this approach to teaching has lost its significance. The students get information at their fingertips and the teacher is no longer the only source of knowledge. While the role of a teacher is still central in a classroom environment, it has slowly transitioned from a teacher to a facilitator. Collaborative Learning is that approach that assists in enhancing the joy of the teaching-learning process [1] by bringing in active learning into the classroom.

Traditionally, engineering education is delivered through a series of classroom lectures, which includes theory as well as associated problem sets, laboratories to complement the classroom lectures and a final year project [2]. These techniques [3] were valid until the entry of the internet, which now acts as an information repository providing anything and everything that a student needs. To improvise the learning experiences in an engineering classroom, strategies such as active learning [4-6], come in handy.

Collaborative Learning, which is a popular form of active learning, is a process of constructing knowledge through interaction with others [7]. While cooperation among the participants lies at its core, it is essentially made up of an instructional method involving cooperation and interaction between learners [8], with necessary support from the teacher. Further, Collaborative Learning falls into the bracket of Team Learning [9] wherein the course facilitators recognize that the subject is to be learned by the learners. In turn, the learners approach classes by preparing well in order to demonstrate the comprehension that they have acquired about the course based on certain preparedness assurance assessments, both as individuals to begin with and then in teams that they get into. Upon this, the learners then apply this comprehension to choose and share solutions to the sets of problems posed to them, first within the team and then in inter-team discussions.

A whole lot of people have the perception that any activity that is done in a group is a collaborative activity. For example, activities like Think-Pair-Share, Think Aloud Pair Problem Solving (TAPPS) [10], In-Class Teams, group seminars, and group assignments are all Collaborative Learning activities is what the popular belief is. However, the above falls under the bracket of Active Learning [11]. Collaborative Learning is the one in which a set of people work together [12] for a considerable amount of time such that the bondage continues beyond the boundaries of the actual activity itself.

Techniques for successful application of collaborative activities are:

- Creating productive teams

- Assist learners in inculcating skills of gelling with each other even before the commencement of the collaborative work

- Facilitating collaboration

- Dealing with conflicts among team members Once the collaborative activity is implemented, it has to be assessed [12] with the help of: 
- Individual and team assessments

- Peer evaluation

- Assessment at each stage of collaboration

- Reflections on errors and failures as well as to success and achievements

This paper focuses on a study that is based on the implementation of Collaborative Learning on a set of students and measures its impact post-assessment.

\section{Literature Review}

As per Smith and MacGregor [14], Collaborative Learning may consist of activities that may substantially differ from each other. However, the prime emphasis has to be on learner's exploration of the course resources instead of the teacher's ability to present it effectively.

Talking about professional development through collaboration, Brown and Lara [15] cite Johnsons [16] who mention the fact that there are methods by virtue of which people take independent action in connection to the actions of others. The steps taken by an individual may assist the success of the rest, choke the success of others or in some cases may not even have an impact on the success or failure of the rest of the members. In other terms, individuals must work as a team in a cooperative environment to achieve learning objectives that are shared, go against each other in a competitive manner so as to accomplish a goal that only one individual or a few people put together can achieve, work completely on an individual basis to attain goals which differ completely from the goals of the rest.

Collaboration is a fairly encouraging means of human arrangement that has turned out to be a fashion in modern times. The necessity to gel and put in efforts together on some very crucial issues has gone up a notch [17-18], resulting in emphasizing teamwork instead of individual work and from autonomy to the community [19].

A notable advantage of Collaborative Learning is in terms of the teams functioning together for a relatively long duration during a particular course. Due to this, the members in teams get to know in addition to understanding each other better, thereby extending the horizon of work beyond the boundaries of the classroom. The students who are also team members get to frequently get in touch with each other to get assistance for the nagging questions or issues that they are having and they often continue to communicate with each other, even at a later stage of their studies [20]. Collaborative Learning aids in developing learning circles within classes, colleges and institutes [21].

\section{Methodology}

The topic chosen to drive home Collaborative Learning was to design attractive and user friendly user interfaces for a specific mobile app. Having completed the discussion on the importance of mobile apps and designing mobile user interfaces during the previous lectures, the time was now right to actually get into the practicalities of development of mobile user interfaces. It is said that design is a very creative activity and when it is done through collaboration, it could be made more creative due to ideas emanating from all collaborators.
Even though the implementation of collaborative activity is crucial, planning collaborative activity is also equally crucial. If the activity is planned well, it is half the job done. Some of the things to be kept in mind include:

1. Choosing the most appropriate collaborative activity from among the available options is central to the success of the activity.

2. Setting objectives for collaborative activity is essential.

3. During the implementation of collaborative activity, it is essential to:

- Have a strategy to divide the students into teams

- Keep the discussions going in the teams

- Motivate individuals who are not contributing to the team

4. Deciding on the time to be given to accomplish the collaborative work.

5. Carrying out assessments at the individual as well as group level and both at formative and summative levels.

\section{A. Participants}

The participants for this study were 32 third year, full-time students from the postgraduate department in computer applications and two teachers of the same department.

\section{B. Study Design}

The students were divided into teams based on varying learning abilities among all learners in the class. The motive was to create heterogeneous teams. The collaborative activity chosen was termed Team-GamesTournament (TGT) [22]. The gist of team formation was as follows:

- Divide learners into three pools namely Right Students or students with High Learning Skills (HLS), Left Students or students with relatively Low Learning Skills (LLS) and Average Students or students with Mid-level Learning Skills (MLS) based on their learning abilities.

- The students learning abilities were identified through performances in a series of diagnostic tests given after the first internal test of the previous semester.

- The materials for the diagnostics were based on multiple courses taught by the authors in the department that the students had earlier taken.

- The diagnostic tests were designed to be challenging in terms of the needed time, with an emphasis on questions that test the skills of applying, analyzing and synthesizing.

- The learners were then made into a group of 3 learners each.

- The groups were designed such that each individual group would consist of a student with HLS, a student with LLS and a student with MLS.

- Thus, each group would contain students with 
different ability levels so that the average ability level of each group was approximately the same.

\section{Team Formation}

Since the total student strength was 32, the students were divided into 8 teams with 4 learners each, based on the results of the pre-test. The teams were formed in such a way that a team would consist of one learner with High Learning Skills, one learner with Low Learning Skills and 2 learners with Mid-level Learning Skills.

Once the teams were formed, each team was numbered. Since there were 8 teams, the teams were numbered sequentially starting from 1 all the way till 8 . Hence, there were eight teams namely: Team 1 , Team 2, Team 3, Team 4, Team 5, Team 6, Team 7 and Team 8. As soon as teams were numbered, each individual member of the team was numbered as well. Since there were four members each in a team, the members were named A, B, C and D. While naming, care was taken so that in all teams, the student with High Learning Skills was named as ' $A$ ' and the student with Low Learning Skills was numbered ' $D$ '. To add to this, due care was taken to name the learners with Mid-Level Learning Skills as ' $\mathrm{C}$ ' and ' $\mathrm{B}$ '.

Once the teams came up with a mobile user interface design for the given specification, the students were regrouped according to their names. To be more specific, A's of all teams were brought together to form a group. At this point, there were 8 A's forming a subgroup and these A's were to compete against each other by means of a group discussion and a quiz to be anchored by the teacher. Similarly, all B's, C's and D's would compete against each other. Hence, during this stage, there were four teams of eight members each. Fig. 1 shows the collaborative activity in progress.

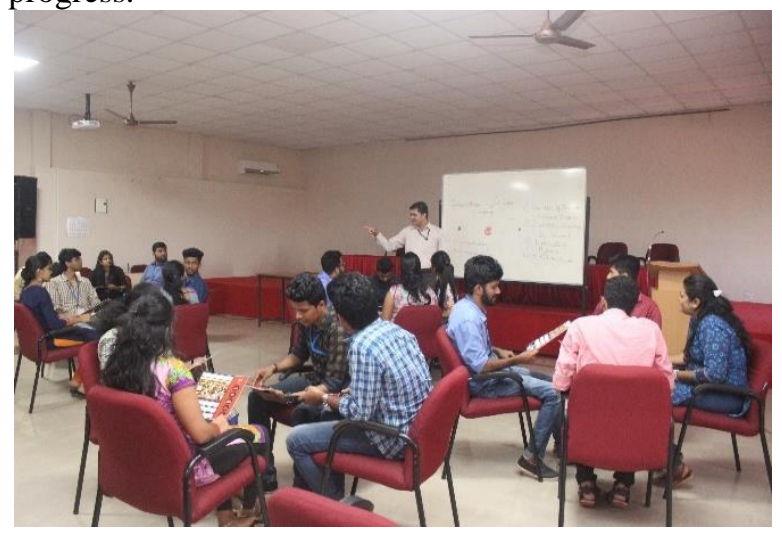

Fig. 1 Collaborative activity in progress

The topic for discussion and the questions asked through the quiz were all different for all these teams. These questions were prepared keeping the learning abilities of the groups in mind. Therefore, the assessments for the group having all A's were slightly on the complex side while the assessments for the group having all D's were slightly on the simpler side. The assessments for B's and C's were moderately designed, keeping their learning abilities as the base.

This activity was conducted over a period of 4 days. The first 3 days were meant for the students to work collaboratively on the given task and on the final day their learning was assessed, both individually and in a group.

\section{Evaluation}

The evaluation of individual and team performances was as follows:

1) Individual Formative (5): This assessment was based on facilitators' observations of individual participation at the time of collaborating with the rest of the learners in the team. This was a combination of observation during lecture hours and through Google Classroom [23]. The course website was created on Google Classroom to continuously foster discussions and monitor the participation. For this activity too, a few resources were posted and a few small tasks were assigned to be completed in isolation. However, it was created in such a way that if any of the team members gets stuck because of some difficulty, the rest of the team members could chip in and contribute to the overall success of the team. These 2 forums gave a fair idea of how the learners as individuals were taking part in this activity. The scores assigned as Individual Formative scores were a reflection of both these facets.

2) Individual Summative (10): This assessment was the sum of group discussion (5) and quiz (5). The group discussion and quiz were customized as per the learning abilities. Both these assessments were conducted in the classroom on the 4th day and were anchored by the facilitator. This was conducted once the teams were regrouped and the new groups were formed. The group discussion was on some vital aspects of user interface design specific to the problem description and the quiz also was designed to test the individual knowledge of each learner. By the end of the summative assessment, the individual learning among the team members had come to the forefront.

3) Group Formative (15): This assessment was based on the facilitator's observations on the extent to which the teams were collaborating during the initial phase. If there was no much meaningful discussion happening within the group, a low score was assigned to such groups. The groups were observed both during the lecture hours and on Google Classroom as was mentioned above.

Apart from this, a group quiz was conducted to have a check on the learning within the group and also to have presentations by the groups to gauge their level of understanding of the concept. Group Formative scores were a summation of all of the above. The scores were broken down as:

- Observations: 5

- Quiz: 5

- Presentations: 5 
4) Group Summative (20)

This was calculated based on the total individual summative assessments of all team members. The total was calculated for 40 marks (10*4) and scaled down to 20.

The activity was evaluated based on the below rubric:

Table 1. The rubric used for Evaluation

\begin{tabular}{|c|c|c|c|c|}
\hline Criteria & \multicolumn{3}{|c|}{ Rating } & Points \\
\hline $\begin{array}{c}\text { Individual } \\
\text { Formative }\end{array}$ & $\begin{array}{c}\text { 5 points } \\
\text { Very } \\
\text { Good }\end{array}$ & $\begin{array}{c}\text { 3 points } \\
\text { Fairly } \\
\text { Good }\end{array}$ & $\begin{array}{c}\text { 0 points } \\
\text { Very } \\
\text { Poor }\end{array}$ & 5 \\
\hline $\begin{array}{c}\text { Individual } \\
\text { Summative }\end{array}$ & $\begin{array}{c}\text { 10 points } \\
\text { Very } \\
\text { Good }\end{array}$ & $\begin{array}{c}\text { 5 points } \\
\text { Fairly } \\
\text { Good }\end{array}$ & $\begin{array}{c}\text { 0 points } \\
\text { Very } \\
\text { Poor }\end{array}$ & 10 \\
\hline $\begin{array}{c}\text { Collective } \\
\text { Formative }\end{array}$ & $\begin{array}{c}\text { 15 points } \\
\text { Very } \\
\text { Good }\end{array}$ & $\begin{array}{c}\text { 8 points } \\
\text { Fairly } \\
\text { Good }\end{array}$ & $\begin{array}{c}\text { 0 points } \\
\text { Very } \\
\text { Poor }\end{array}$ & 15 \\
\hline $\begin{array}{c}\text { Collective } \\
\text { Summative }\end{array}$ & $\begin{array}{c}\text { 10 points } \\
\text { Very } \\
\text { Good }\end{array}$ & $\begin{array}{c}\text { 5 points } \\
\text { Fairly } \\
\text { Good }\end{array}$ & $\begin{array}{c}\text { 0 points } \\
\text { Very } \\
\text { Poor }\end{array}$ & 20 \\
\hline
\end{tabular}

At the end of this collaborative activity, the team with the best scores was declared the winner and all team members were rewarded.

\section{Results and Discussion}

While the collaborative work was in progress, the followings were to be looked at with keen interest to ensure the success of the activity:

- Keeping the discussion going amongst the team members

- Motivating non participating members

- Opening a deadlock situation

Table 2 shows the team-wise scores at the end of the activity.

\begin{tabular}{|c|c|c|c|c|}
\hline $\begin{array}{c}\text { Team } \\
\text { No. }\end{array}$ & $\begin{array}{c}\text { No. } \\
\text { of } \\
\text { Stud } \\
\text { ents }\end{array}$ & $\begin{array}{c}\text { Team } \\
\text { Score } \\
\text { (Median } \\
\text { Score= } \\
\text { 40.625) }\end{array}$ & $\begin{array}{c}\text { Team } \\
\text { Performe } \\
\text { d less } \\
\text { than the } \\
\text { median } \\
\text { score } \\
(\mathrm{Y} / \mathrm{N})\end{array}$ & $\begin{array}{c}\text { One most } \\
\text { important } \\
\text { reason for the } \\
\text { team's } \\
\text { performance }\end{array}$ \\
\hline 1 & 4 & 45 & No & $\begin{array}{lr}\text { Equal } & \\
\text { participation in } & \\
\text { discussions from } & \text { team } \\
\text { all } & \text { trembers. } \\
\text { mem } & \\
\text { It } & \text { was } \\
\text { commendable to } \\
\text { see } & \text { team } \\
\text { members } & \\
\text { (especially } & \text { the } \\
\text { one with } & \text { HLS) } \\
\text { allowing } & \text { equal } \\
\text { participation } & \text { from } \\
\text { all } & \text { team } \\
\text { members. } & \text { This }\end{array}$ \\
\hline
\end{tabular}

\begin{tabular}{|c|c|c|c|c|}
\hline & & & & $\begin{array}{l}\text { allowed students } \\
\text { with LLS to } \\
\text { flourish and } \\
\text { contribute to the } \\
\text { success of the } \\
\text { team. }\end{array}$ \\
\hline 2 & 4 & 40 & Yes & $\begin{array}{l}\text { Inability to } \\
\text { sustain } \\
\text { performance } \\
\text { whilst } \\
\text { subgroups. } \\
\text { While this team } \\
\text { had done well, } \\
\text { the slight dip in } \\
\text { their performance } \\
\text { was due to the } \\
\text { fact that when the } \\
\text { team was broken } \\
\text { into subgroups, } \\
\text { the students with } \\
\text { LLS could not } \\
\text { cope up with } \\
\text { some of the other } \\
\text { LLS students } \\
\text { from other teams } \\
\text { which eventually } \\
\text { brought their } \\
\text { scores down. }\end{array}$ \\
\hline 3 & 4 & 32.5 & Yes & $\begin{array}{l}\text { Lack of interest } \\
\text { and } \\
\text { participation. } \\
\text { This team was the } \\
\text { least performing } \\
\text { team. From the } \\
\text { beginning, these } \\
\text { had little interest } \\
\text { in the activity and } \\
\text { there was not too } \\
\text { much } \\
\text { collaboration } \\
\text { among the group } \\
\text { members. Even } \\
\text { after pushing } \\
\text { them to be active, } \\
\text { there was a lack } \\
\text { of interest which } \\
\text { eventually was } \\
\text { seen in their } \\
\text { overall scores. }\end{array}$ \\
\hline
\end{tabular}




\begin{tabular}{|c|c|c|c|c|}
\hline 4 & 4 & 40 & Yes & $\begin{array}{l}\text { Inability to } \\
\text { sustain } \\
\text { performance } \\
\text { whilst in } \\
\text { subgroups. } \\
\text { It was a moderate } \\
\text { show by this } \\
\text { team. The reasons } \\
\text { were similar to } \\
\text { that of Team 2's } \\
\text { performance. } \\
\text { Where they lost } \\
\text { out was when } \\
\text { competing against } \\
\text { other people with } \\
\text { similar abilities. }\end{array}$ \\
\hline 5 & 4 & 47.5 & No & $\begin{array}{l}\text { Collaboration } \\
\text { and teamwork. } \\
\text { By far, the best } \\
\text { performing team. } \\
\text { Their success } \\
\text { could be } \\
\text { attributed } \\
\text { meticulous } \\
\text { planning } \\
\text { fantastic } \\
\text { execution. } \\
\text { Collaboration and } \\
\text { teamwork was the } \\
\text { hallmark of this } \\
\text { team and that is } \\
\text { why they could } \\
\text { outperform the } \\
\text { rest. }\end{array}$ \\
\hline 6 & 4 & 40 & Yes & 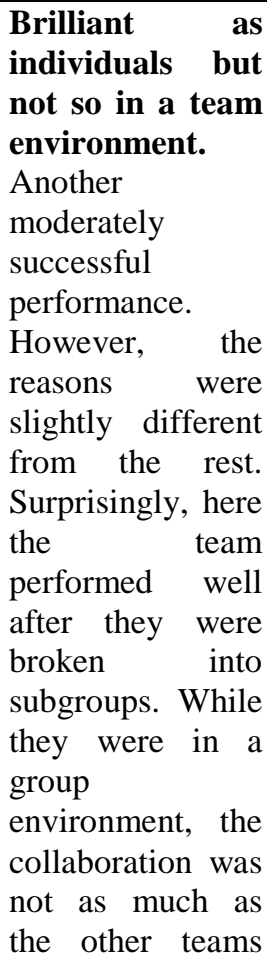 \\
\hline
\end{tabular}

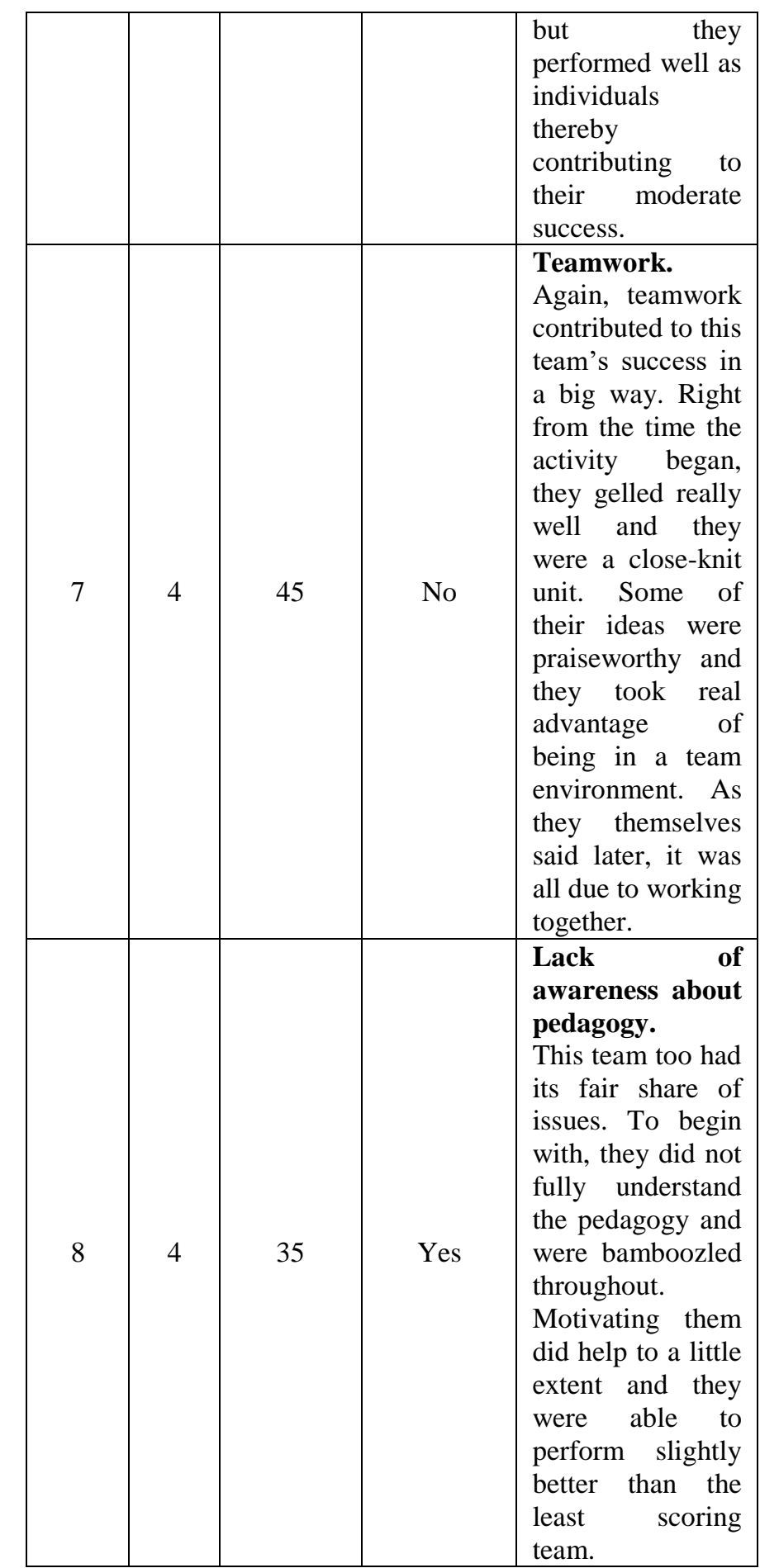

As the results clearly show, the teams with the best scores were right up there because of their collaborative group work. The teams performing below the median score did have some brilliant individual performers but they could not gel well as a team. Hence, relatively low scores.

Considering the above results, if the collaborative activity were to be conducted again, the following measures could be taken to improvise it further:

- The above activity was done over a period of 4 days. It would be better to try to limit it to a day. In hindsight, it is better to divide students into teams; conduct the activity and finish the assessment at one go rather than have 
them done over multiple days. Once the students are let out after a class, they usually do not follow it up and continue to work on it. Even though this above activity was conducted over 4 days, in essence, the students worked only for 5-6 hours. The rest of the time was unutilized.

- It would be best to have the teams define team goals or objectives at the beginning itself. If an objective is set, the teams could work progressively towards achieving it. In the above activity, some of the teams lacked goals and they wandered off track for the most part of the activity. Setting clear goals/objectives is what the teams should do to ensure success. In addition to it, teams could be given some small subtasks that may keep the participation going and end up keeping the team active throughout.

The affirmative to the learning was the responses from the class at the conclusion of the activity. There was a lot of well thought of responses as shown in Fig. 2 and it was a testimony to the amount of learning they had during the session.

\begin{tabular}{|c|c|}
\hline Si No & Feedback and Suggestions \\
\hline 1 & Good experience \\
\hline 2 & Innovative but difficult \\
\hline 3 & New experince and lots to learn out of it. Please do it often.. \\
\hline 4 & $\begin{array}{l}\text { Classroom sessions are boring. We need more such activities } \\
\text { and they have to be conducted regulary. Please remove theory } \\
\text { classes completely. }\end{array}$ \\
\hline 5 & Could have been done better \\
\hline 6 & Need more such assessments to understand where we stand \\
\hline 7 & Usefull overall \\
\hline 8 & Good \\
\hline 9 & New experince, beneficial too \\
\hline
\end{tabular}

Although TGT brings out individual learning, there was a lot of knowledge transfer among the members of the groups. Expert groups were even better, where each was trying to drive home their point of view and a lot of brainstorming was on display. Also, as the students had to listen to each other, there was a lot of listening going on along with putting their points forward. This created a Group Discussion sort of atmosphere that brought out the competitive edge among the students.

While everything looks to be bright and sunny, there were few gray areas that need to be looked at:

1. Initially, the students were lost and had no idea of how things would pan out. While most of the students were quite clear with the motive behind the activity, some of them were still not clear on the takeaways. In such situations, it is the responsibility of the teacher to intervene and bring sanity into proceedings.

2. The time allocated to accomplish Collaborative Learning is a factor that needs to be looked at very carefully. It is better to devise strategies to make better utilization of time.

3. When groups tend to deviate from the task, again it becomes essential that the teacher intervenes and gets the teams back on track.

4. Lack of participation in some of the teams is another thing that needs close monitoring. The active members in the teams usually make up for the lack of interest shown by their teammates. However, as far as possible, such situations must be dealt with appropriately.

Although Collaborative Learning was leveraged once and the assessment methods were set for the activity conducted, the authors intend to run the next iteration on the same set of students with modifications to the rubric in order to check if the student's performances improve due to collaboration. Also, the authors intend to gauge the impact of Collaborative Learning in terms of the student's performances in parameters like academics, preparations for placements and soft skills among others. While the feedback looks promising, the conduction of these activities over multiple iterations is certain to provide some more insights on the action to be taken on the feedback. In addition to the above, comparing the above method with some of the existing methods might open up avenues for further research in this area.

\section{Conclusion}

Reflecting on Collaborative Learning, the implementation of the above activity shows the worth of such collaborative work. When the students are divided into teams and are given a task of accomplishing something, they most often than not put in their best foot forward and try to get the task done, because of the competitive nature of the team environment, as it was quite evident in case of the above experiment. However, even though the general tendency is to feel that the formation of teams is a very trivial step, it is not the case. A lot of thought has to be given to come up with these teams and the intent should be to create heterogeneous teams. If a lot of care is not given to team formation and it goes wrong, there is a risk of the whole activity not living up to expectations. Therefore, it is worth investing a huge chunk of time to meticulously plan the formation of teams during Collaborative Learning. It is indeed not straightforward.

If done well, Collaborative Learning acts as a paradigm shift for most of the students as they get to move away from quick and witty active learning techniques to more elaborate ways of collaborating with their peers and sharing their views. This eventually contributes to the success of teams. Since it is a competitive group task, most of the groups tend to be very active and the group members try to help each other out to achieve their team goals.

\section{References}

[1] Ganesh, K. E., \& Pranesha, T. S. (2018). Enhancement of Learning Outcomes through Implementation of best practices in Teaching Learning Process: A case study. Journal of Engineering Education 
Transformations, 32(1), 12-14. 1

[2] Felder, R. M., Woods, D. R., Stice, J. E., \& Rugarcia, A. (2000). The future of engineering education II. Teaching methods that work. Chemical Engineering Education, 34(1), 26-39.

[3] Felder, R. M., \& Brent, R. (2005). Understanding student differences. Journal of engineering education, 94(1), 57-72.

[4] Wankat, P. C., \& Oreovicz, F. S. (2015). Teaching engineering. Purdue University Press.

[5] Waldrop, M. M. (2015). The science of teaching science. Nature, 523(7560), 272.

[6] Bradforth, S. E., Miller, E. R., Dichtel, W. R., Leibovich, A. K., Feig, A. L., Martin, J. D., ... \& Smith, T. L. (2015). University learning: Improve undergraduate science education. Nature News, 523(7560), 282.

[7] Jadhav, M. R. (2016). Use of Active and Collaborative Learning Techniques in the Course Digital Communication of Electronics and Telecommunication Engineering. Journal of Engineering Education Transformations, 30(2), 119-122.

[8] Desai, T. S., \& Kulkarni, P. P. (2016). 'Cooperative Learning'Tool for Optimizing Outcomes of Engineering Education. Journal of Engineering Education Transformations.

[9] Manohar, S. J. (2017). 'Team Learning' as an Innovative Pedagogical Tool: A Study among'EE Generation'in Bangalore. Journal of Engineering Education Transformations.

[10] Perumaal, S. S. (2018). Creating an Effective Learning Environment in Engineering Graphics Course for First Year Engineering Students. Journal of Engineering Education Transformations.

[11] Aluvalu, R. K., Kulkarni, V., \& Asif, M. (2017). Handling Classrooms with Students having Heterogeneous Learning Abilities. Journal of Engineering Education Transformations, 30(3), 229234.

[12] Rambabu, M., Ramana, N., \& Sadanandam, M. (2018). An Active and Collaborative Learning Practice through Mind Mapping Using Jigsaw Activity of Class Room Based Interaction in Engineering Education. Journal of Engineering Education Transformations.

[13] Diaz, V., Brown, M., \& Salmons, J. (2010). Assessment of collaborative learning project outcomes. Educause Learning Initiatives.

[14] Smith, B. L., \& MacGrecor, J. T. (1992). What is collaborative learning? In (Eds) A. Goodsell, M. Maher, V. Tinto, BL Smith \& J. MacGregor. Collaborative learning: A sourcebook for higher education.

[15] Brown, L., \& Lara, V. (2011). Professional development module on collaborative learning. El Paso Community College, Texas: USA. Retrieved Jan, 5, 2012.

[16] Johnson, D. W., \& Johnson, R. T. (2009). An educational psychology success story: Social interdependence theory and cooperative learning. Educational researcher, 38(5), 365-379.

[17] Austin, J. E. (2000). Principles for partnership.

[18] Laal, M., \& Ghodsi, S. M. (2012). Benefits of collaborative learning. Procedia-social and behavioral sciences, 31, 486-490.

[19] Leonard, P. E., \& Leonard, L. J. (2001). The collaborative prescription: Remedy or reverie? International Journal of Leadership in Education, 4(4), 383-399.
[20] Bean, J. C. (2011). Engaging ideas: The professor's guide to integrating writing, critical thinking, and active learning in the classroom. John Wiley \& Sons.

[21] Tinto, V. (1997). Enhancing learning via community. Thought \& Action, 13(1), 53-58.

[22] DeVries, D. L. (1976). Teams-games-tournament: a gaming technique that fosters learning. Simulation \& Games, 7(1), 21-33.

[23] Bhat, S., Raju, R., Bikramjit, A., \& D'Souza, R. (2018). Leveraging E-learning through Google classroom: A usability study. Journal of Engineering Education Transformations, 31(3), 129-135. 